\title{
Attitude and Perception of Physicians towards Adverse Drug Reaction Reporting in Saudi Arabia
}

\author{
Yousef Ahmed Alomi* iD, BSc. Pharm, MSc. \\ Clin Pharm, BCPS, BCNSP, DiBA, CDE \\ Critical care clinical pharmacists, TPN clinical \\ pharmacist, Freelancer Business Planner, \\ Content Editor and Data Analyst, Riyadh, \\ SAUDI ARABIA \\ Nouf Hassan Alamoudi, PharmD \\ Umm Al-Qura University, Makkah, SAUDI \\ ARABIA. \\ Sabah Alanazi, B.D.S \\ Prince Sultan Medical Military City, Riyadh, \\ SAUDI ARABIA \\ Abeer Hussin Almasoudi, BSc.Pharm \\ Director, Administration of research and studies, \\ Ministry of Health, Tabuk, SAUDI ARABIA
}

\section{Correspondence:}

Dr. Yousef Ahmed Alomi, BSc. Pharm,

MSc. Clin Pharm, BCPS, BCNSP, DiBA, CDE

Critical care clinical pharmacists, TPN Clinical

Pharmacist, Freelancer Business Planner,

Content Editor and Data Analyst, P.O.BOX 100

Riyadh-11392, Riyadh, SAUDI ARABIA

Phone no: +966504417712

E-mail: yalomi@gmail.com
Received: 15-09-2021;

Accepted: 10-11-2021

Copyright: (c) the author(s), publisher and licensee International Journal of Pharmacology and Clinical Sciences. This is an open-access article distributed under the terms of the Creative Commons Attribution Non-Commercial License, which permits unrestricted non-commercial use, distribution, and reproduction in any medium, provided the original work is properly cited.

This is an open access article distributed under the terms of the Creative Commons Attribution-NonCommercial-ShareAlike 4.0 License

Access this article online

\begin{tabular}{|c|c|}
\hline & www.ijpcs.net \\
\hline & DOI: \\
\hline
\end{tabular}

\begin{abstract}
Objectives: Spontaneous reporting systems are indispensable as they aid perceive serious unknown adverse drug reaction (ADR). To assess the physician's perceptions and attitudes of adverse drug reaction reporting in the Kingdom of Saudi Arabia. Methods: It was a cross-sectional study with an authenticated survey distributed to different physicians and dentists in Saudi Arabia. A self-administered electronic survey involved of demographic data and perception of the ADR reporting system and factor facilitated or prevented reporting system. Results: The total number of participants was 151. Of those, $111(73.5 \%)$ were physicians, while dentists were $39(26.5 \%)$. The average score physician's perception about the prominence of the ADR reporting system was 4.46, with a statistically noteworthy difference within answers of each component $(p<0.05)$ The average score of the physician's perception of factors that enabled the ADR reporting system was 4.13 with a statistically momentous difference within answers of each component $(p<0.05)$. The average scores of perception physicians were 3.13 , with a statistically significant difference between the responses of each facet $(p<0.05)$. Conclusion: The physicians' perception of ADR and related issues was optimistic. The physicians request periodic training of ADR identification and reporting program. The pharmacist plays a perilous responsibility to improve the ADR system with healthcare providers.

Key words: Physician, attitude, Perception, Reporting, Adverse drug reaction, Saudi Arabia
\end{abstract}

\section{INTRODUCTION}

In 1969, the WHO well-defined Adverse Drug Reactions (ADRs) as any noxious unintended reaction to a drug which happen at normal doses employed in the prophylaxis, diagnosis or the treatment of diseases. When healthcare professionals distinguish ADR reports through preceding information about it, they have inadequate training about the $\mathrm{ADR}$ reporting process, so that undesirable effect on perception or might barriers avert reporting; then lead to an underreporting delinquent. Also, imperfect knowledge leads to it. Over the past twenty years, more than forty studies have deliberated ADR reporting or pharmacovigilance and physicians' perceptions. The physicians' perception of ADR and reporting system was showed with promising results in more than 24 studies and systemic review with 32 studies. More than $80 \%$ or $90 \%$ of physicians felt it vital to report ADR and should be instructed for all physicians to report the ADR. However, various reason depresses reporting; for instance, did not know how to report 26-60\% or dearth time $29-50 \% .{ }^{[1-24]}$ Many studies were conducted to assess perception or attitude toward ADR reporting or pharmacovigilance between healthcare professionals in Saudi Arabia. At King Saud medical city, Riyadh 399 participants (52 physicians of participants), the results specify to $93.8 \%$ of all participants decided that ADR reporting should be made required for healthcare professionals and $94.5 \%$ settled that it improves patient safety. ${ }^{[9]}$
In Al-Khobar at King Fahd Hospital of the University, 331 participants (161 physicians of participant), the outcomes were designated to 87.1\% agreed that ADRs need to be described and $75.9 \%$ decided that it is obligatory. ${ }^{[6]}$ In Jeddah city, 337 hospital physicians participant; the results showed that $90 \%$ of them had a positive attitude toward ADRs, ADRs reporting and monitoring system. ${ }^{[5]}$ In a multi-center study in Saudi Arabia, 336 participants designated $86 \%$ agreed that ADR reporting is a professional obligatory, while $26 \%$ of participants didn't know how to submit an ADR report. ${ }^{[10]}$ Most preceding international or local studies did not comprise factors affecting physicians' perceptions like gender or age, qualifications, positions, or years of experiences showed in Saudi Arabia. Also, the validation and dependability of the survey was not used in many of the studies. As a result, the current study will deliberate the perception only with factors affecting perception using validation and reliability methods. The current study's objective is to state the physician's perception of the ADR reporting system in Saudi Arabia and factoring affection.

\section{METHODS}

It examines a self-administered electronic survey and cross-sectional design of physicians' perception of reporting ADRs in Saudi Arabia. All physicians or dentists who functioned at 
any geographical location in Saudi Arabia will be encompassed in the study. All physicians' qualifications or specialties will be comprised in the study. All students or interns will be omitted from the study. The questioners comprised of two parts. The first one contained of the responder's demographic information. The second one confined the physician's perception of ADR important, factors encouraging physicians to report ADR, barriers preventing and discourage ADR reporting from earlier literatures. ${ }^{[2-26]}$

The 5-point Likert response scale system was employed with closed-ended questions. The sample calculated as cross-sectional study according previous literature with unlimited populations' size, the confidence level 95\% with z score of 1.96, margin of error (5-6.5\%), populations' percentage (50\%) and drop-out rate $(10 \%)$. As results, the sample size will equal to 251 to 432 with power of study of $80 \%$. ${ }^{[27-29]}$ The response rate required of calculated sample size at least $60-70 \%$ and above. ${ }^{[29,30]}$ The survey was guided through whatsapp and telegram as social media tools. Every 1-2 weeks reminder message will be referred to the physicians.

The survey was authorized through the reconsideration of expert reviewers and pilot testing. Also, numerous tests of reliability McDonald's $\omega$, Cronbach alpha, Guttmann's $\lambda 2$ and Guttmann's $\lambda 6$ had been finished with the study. The survey analysis through monkey survey system, the statistical package of social sciences (SPSS), Jeffery's Amazing Statistics Program (JASP), Microsoft excel sheet version 16 with description and frequency analysis, good of fitness analysis, correlation analysis, inferential analysis of factors affects physician's knowledge of $\mathrm{ADR}$ and reporting system. The STROBE (Strengthening the reporting of observational studies in epidemiology statement: guidelines for reporting observational studies) directed the reporting of the current study. ${ }^{[31,32]}$

\section{RESULTS}

The total number of participants was 151 with response rate $(60.15 \%)$. Of those 111 (73.5\%) were physicians, while 39 (26.5\%) were dentists. Most responders from central and north area $76(50.68 \%)$ and $27(18 \%)$, respectively with statistically noteworthy among all regions $(p<0.05)$. The gender distribution was male $83(54.97 \%)$ and female was 68 (46.03\%) with statistically non-significant among them $(p>0.05)$. Most participants were in age (2436) years $82(54.3 \%)$ and age (36-45) years 29 (19.21\%) with statistically important between them $(p<0.05)$.Many of the responder' experiences were residents $62(41.33 \%)$ and consultants 42 (28\%), while most of the participants held physicians or dental staff jobs 116 (77.33\%) with statistically noteworthy between all physician qualifications types and position jobs $(p<0.05)$. Most of the responders had more than nine years' experience, 60 (40\%) and (1-3) years' experience 35 (23.33\%) with a statistically significant length of experience levels $(p<0.05)$. The most physicians' participants were medical $19(12.67 \%)$ and surgical field was 17 (9.33\%), while the dentist's specialisms were curative dentistry 9 (12.16\%) from the total number of participants with statistically significant among all subjects $(p<0.05)$ (Table 1 and 2).

\section{Perception of ADR Reporting}

The average scores of physician's insights about the prominence of the ADR reporting system were 4.46 with statistically significant alterations within answers of each element $(p<0.05)$. The highest score level was to classify the factors predisposed to ADR (4.59), while the lowest scores were to compare ADR between the pharmaceutical manufacturer (4.28) (Table 3 ). The average scores of factors that eased the physicians reporting of ADR were 4.13 with

\begin{tabular}{|c|c|c|c|}
\hline Nationality & Response Count & Response Percent & $P$-Value \\
\hline Central area & 76 & $50.67 \%$ & \multirow[t]{5}{*}{$<0.05$} \\
\hline North area & 27 & $18.00 \%$ & \\
\hline South area & 12 & $8.00 \%$ & \\
\hline East area & 16 & $10.67 \%$ & \\
\hline West area & 19 & $12.67 \%$ & \\
\hline Answered question & 150 & & \\
\hline Skipped question & 1 & & \\
\hline Gender & Response Count & Response Percent & \\
\hline Male & 83 & $54.97 \%$ & \multirow[t]{2}{*}{$>0.05$} \\
\hline Female & 68 & $45.03 \%$ & \\
\hline Answered question & 151 & & \\
\hline Skipped question & 0 & & \\
\hline Age & Response Count & Response Percent & \\
\hline $24-35$ & 82 & $54.30 \%$ & $<0.05$ \\
\hline $36-45$ & 29 & $19.21 \%$ & \\
\hline $46-55$ & 16 & $10.60 \%$ & \\
\hline$>55$ & 24 & $15.89 \%$ & \\
\hline Answered question & 151 & & \\
\hline Skipped question & 0 & & \\
\hline
\end{tabular}

a statistically significant difference within answers of each element $(p<0.05)$. The highest score level was if the ADR is serious (4.63), followed by the ADR for the new product (4.41) and periodic training of medical staff about ADR (4.35), while the lowest scores factors were the ADR reporting system should be non-compulsory and paid (2.95), followed by well-known of ADR of a precise drug (4.03) and easy method of reporting system (4.06) (Table 4).

The average scores of factors that might avert physicians from reporting ADR were 3.13 with a statistically important difference within answers of each element $(p<0.05)$. The highest score level was the physician's level knowledge of the ADR reporting system (3.92), indeterminate between ADR and medications (3.9) and ignorant of the existing national ADR reporting system (3.79). In contrast, the lowest scores factors were worry that's ADR reporting will produce extra work (3.08), lack of financial reimbursement (3.13) and lack of time to fill the reports (3.22) (Table 5). The reliability test of McDonald's $\omega$ (0.912), Cronbach alpha 


\begin{tabular}{|c|c|c|c|}
\hline $\begin{array}{c}\text { Physician } \\
\text { Qualifications }\end{array}$ & $\begin{array}{l}\text { Response } \\
\text { Count }\end{array}$ & $\begin{array}{c}\text { Response } \\
\text { Percent }\end{array}$ & $\begin{array}{c}P \text { - } \\
\text { value }\end{array}$ \\
\hline Intern & 9 & $6.00 \%$ & $\begin{array}{c}< \\
0.05\end{array}$ \\
\hline Resident & 62 & $41.33 \%$ & \\
\hline $\begin{array}{l}\text { General } \\
\text { Practitioner }\end{array}$ & 10 & $6.67 \%$ & \\
\hline Specialist & 27 & $18.00 \%$ & \\
\hline Consultant & 42 & $28.00 \%$ & \\
\hline $\begin{array}{l}\text { Answered } \\
\text { question }\end{array}$ & 150 & & \\
\hline $\begin{array}{l}\text { Skipped } \\
\text { question }\end{array}$ & 1 & & \\
\hline Position Held & $\begin{array}{l}\text { Response } \\
\text { Count }\end{array}$ & $\begin{array}{c}\text { Response } \\
\text { Percent }\end{array}$ & \\
\hline $\begin{array}{l}\text { Director } \\
\text { of medical unit }\end{array}$ & 14 & $9.33 \%$ & $\begin{array}{c}< \\
0.05\end{array}$ \\
\hline $\begin{array}{l}\text { Assistant } \\
\text { director of the } \\
\text { medical unit }\end{array}$ & 5 & $3.33 \%$ & \\
\hline $\begin{array}{l}\text { Medical } \\
\text { Director }\end{array}$ & 14 & $9.33 \%$ & \\
\hline $\begin{array}{l}\text { Physician or } \\
\text { Dentist staff }\end{array}$ & 116 & $77.33 \%$ & \\
\hline $\begin{array}{l}\text { Program } \\
\text { Coordinator }\end{array}$ & 1 & $0.67 \%$ & \\
\hline $\begin{array}{l}\text { Answered } \\
\text { question }\end{array}$ & 150 & & \\
\hline $\begin{array}{l}\text { Skipped } \\
\text { question }\end{array}$ & 1 & & \\
\hline
\end{tabular}

\begin{tabular}{|l|c|c|c|}
\hline $\begin{array}{c}\text { Years of } \\
\text { experiences } \\
\text { in the } \\
\begin{array}{c}\text { Physician } \\
\text { career }\end{array}\end{array}$ & $\begin{array}{c}\text { Response } \\
\text { Count }\end{array}$ & $\begin{array}{c}\text { Response } \\
\text { Percent }\end{array}$ & \\
\hline$<1$ & 21 & $14.00 \%$ & \begin{tabular}{c}
$<.05$ \\
\hline 1
\end{tabular} \\
\hline $1-3$ & 35 & $23.33 \%$ & \\
\hline $4-6$ & 20 & $13.33 \%$ & \\
\hline $7-9$ & 14 & $9.33 \%$ & \\
\hline$>9$ & 150 & $40.00 \%$ & \\
\hline $\begin{array}{l}\text { Answered } \\
\text { question }\end{array}$ & 1 & & \\
\hline Skipped \\
question
\end{tabular}

\begin{tabular}{|c|c|c|c|}
\hline Surgical & 17 & $11.33 \%$ & \\
\hline Pediatrics & 14 & $9.33 \%$ & \\
\hline Anesthesia & 1 & $0.67 \%$ & \\
\hline Psychiatry & 2 & $1.33 \%$ & \\
\hline $\begin{array}{l}\text { Obstetrics and } \\
\text { Gynecology }\end{array}$ & 7 & $4.67 \%$ & \\
\hline Dentistry & 39 & $26.00 \%$ & \\
\hline $\begin{array}{l}\text { Family } \\
\text { medicine }\end{array}$ & 13 & $8.67 \%$ & \\
\hline Non applicable & 1 & $0.67 \%$ & \\
\hline $\begin{array}{l}\text { Other (please } \\
\text { specify) }\end{array}$ & 25 & $16.67 \%$ & \\
\hline $\begin{array}{l}\text { Answered } \\
\text { question }\end{array}$ & & 150 & \\
\hline $\begin{array}{l}\text { Skipped } \\
\text { question }\end{array}$ & & 1 & \\
\hline $\begin{array}{c}\text { Dentist } \\
\text { Specialties }\end{array}$ & $\begin{array}{c}\text { Response } \\
\text { Count }\end{array}$ & $\begin{array}{c}\text { Response } \\
\text { Percent }\end{array}$ & \\
\hline $\begin{array}{l}\text { Dental Public } \\
\text { Health }\end{array}$ & 4 & $5.41 \%$ & $\begin{array}{c}< \\
0.05\end{array}$ \\
\hline Endodontics & 2 & $2.70 \%$ & \\
\hline $\begin{array}{l}\text { Oral and } \\
\text { Maxillofacial } \\
\text { Surgery }\end{array}$ & 3 & $4.05 \%$ & \\
\hline $\begin{array}{l}\text { Oral Medicine } \\
\text { and Pathology }\end{array}$ & 1 & $1.35 \%$ & \\
\hline $\begin{array}{l}\text { Oral and } \\
\text { Maxillofacial } \\
\text { Radiology }\end{array}$ & 0 & $0.00 \%$ & \\
\hline $\begin{array}{l}\text { Orthodontics } \\
\text { and } \\
\text { Dentofacial } \\
\text { Orthopedics }\end{array}$ & 1 & $1.35 \%$ & \\
\hline $\begin{array}{l}\text { Pediatric } \\
\text { Dentistry }\end{array}$ & 4 & $5.41 \%$ & \\
\hline Periodontics & 0 & $0.00 \%$ & \\
\hline Prosthodontics & 2 & $2.70 \%$ & \\
\hline $\begin{array}{l}\text { Restorative } \\
\text { dentistry }\end{array}$ & 9 & $12.16 \%$ & \\
\hline $\begin{array}{l}\text { Special needs } \\
\text { dentistry }\end{array}$ & 0 & $0.00 \%$ & \\
\hline $\begin{array}{l}\text { Family } \\
\text { dentistry }\end{array}$ & 2 & $2.70 \%$ & \\
\hline $\begin{array}{l}\text { General } \\
\text { dentist }\end{array}$ & 4 & $5.41 \%$ & \\
\hline Non-applicable & 39 & $52.70 \%$ & \\
\hline $\begin{array}{l}\text { Other (please } \\
\text { specify) }\end{array}$ & 3 & $4.05 \%$ & \\
\hline $\begin{array}{l}\text { Answered } \\
\text { question }\end{array}$ & 74 & & \\
\hline $\begin{array}{l}\text { Skipped } \\
\text { question }\end{array}$ & 77 & & \\
\hline
\end{tabular}

(0.916), Guttmann's $\lambda 2$ (0.925) and Guttmann's $\lambda 6$ (0.962).

\section{Factors Affecting the Perception of ADR Reporting \\ Gender and Age}

The male gender is more affable than females in the perception of ADR in three goals of the ADR program. Four tools employed to inspire the physician to reports and five factors depress ADR reporting (Table 6). There is no noteworthy difference among all age groups in all rudiments of ADR perception, comprising the reasons of demand ADR reporting system, factors inspire $A D R$ reporting and factors discourage of ADR reporting system $(p>0.05)$.

\section{Qualifications and Specialty}

The consultant had more contracts than residents with noteworthy differences $(p<0.05)$, with most factors inspiring to report ADR. At the same time, no significant difference between all physician experiences $(p>0.05)$ and rudiments that discourage reporting ADR. There is no significant difference among all type of physician specialties (critical care, emergency, medical, surgical, pediatric, anesthesia, psychiatric, family medicine, obstetrics \& gynecology and dentistry) in all elements of ADR perception, including the goal of ADR programs; factors encourage ADR reporting and factors discourage ADR reporting $(p>0.05)$.

\section{Position and Experiences}

There is no important difference between physician places (director of medical units, assistant director of the medical department, medical director and physician staff) and insight of ADR $(p>0.05)$. The expert physician more pacts than nine years experiences than (1-3 years) experiences with significant differences $(p<0.05)$ with three reasons of recognized an ADR program comprising to measure the occurrence of $\mathrm{ADR}$, to classify factors predispose of $\mathrm{ADR}$ and to compare $\mathrm{ADR}$ of the same drug for different pharmaceutical companies. Otherwise, there is significant, among other reasons. There is a momentous difference between an expert physician ( $>9$ years) with more agreements with the mainstream factors encouraging to report ADR than less experience (1-3 years). Also, there is no significant difference between the length of experience and factors that depress reporting ADR. However, there are three factors the less experience (1-3 years) had more contracts than more than nine years in fear of legal liability, ignorant of the need for $\mathrm{ADR}$ reporting system and do not feel the need for recognized reactions for a particular drug. 


\begin{tabular}{|c|c|c|c|c|c|c|c|c|c|c|c|c|c|c|}
\hline \multirow{2}{*}{$\begin{array}{l}\text { No } \\
1\end{array}$} & \multirow{2}{*}{\begin{tabular}{l}
\multicolumn{1}{c}{ Items } \\
$\begin{array}{l}\text { To enable safe drugs to be } \\
\text { identified. }\end{array}$
\end{tabular}} & \multicolumn{2}{|c|}{ Strongly agree } & \multicolumn{2}{|c|}{ Agree } & \multicolumn{2}{|c|}{ Uncertain } & \multicolumn{2}{|c|}{ Disagree } & \multicolumn{2}{|c|}{$\begin{array}{l}\text { Strongly } \\
\text { disagree }\end{array}$} & \multirow{2}{*}{$\begin{array}{c}\text { Total } \\
148\end{array}$} & \multirow{2}{*}{$\begin{array}{c}\text { Weighted } \\
\text { Average } \\
4.58\end{array}$} & \multirow{2}{*}{$\begin{array}{l}P \text {-value } \\
<0.05\end{array}$} \\
\hline & & $68.24 \%$ & 101 & $25.00 \%$ & 37 & $4.05 \%$ & 6 & $2.03 \%$ & 3 & $0.68 \%$ & 1 & & & \\
\hline 2 & $\begin{array}{l}\text { To measure the incidence of } \\
\text { ADRs. }\end{array}$ & $59.46 \%$ & 88 & $34.46 \%$ & 51 & $4.73 \%$ & 7 & $1.35 \%$ & 2 & $0.00 \%$ & 0 & 148 & 4.52 & $<0.05$ \\
\hline 3 & $\begin{array}{l}\text { To identify factors that might } \\
\text { predispose to ADRs. }\end{array}$ & $65.54 \%$ & 97 & $29.05 \%$ & 43 & $4.73 \%$ & 7 & $0.68 \%$ & 1 & $0.00 \%$ & 0 & 148 & 4.59 & $<0.05$ \\
\hline 4 & $\begin{array}{l}\text { To identify previously } \\
\text { unknown ADRs. }\end{array}$ & $60.81 \%$ & 90 & $30.41 \%$ & 45 & $5.41 \%$ & 8 & $2.03 \%$ & 3 & $1.35 \%$ & 2 & 148 & 4.47 & $<0.05$ \\
\hline 5 & $\begin{array}{l}\text { To compare ADRs for drugs in } \\
\text { similar Therapeutic classes. }\end{array}$ & $55.10 \%$ & 81 & $32.65 \%$ & 48 & $8.84 \%$ & 13 & $2.72 \%$ & 4 & $0.68 \%$ & 1 & 147 & 4.39 & $<0.05$ \\
\hline 6 & $\begin{array}{l}\text { To compare ADRs of the same } \\
\text { drug from Different drug } \\
\text { companies. }\end{array}$ & $49.32 \%$ & 73 & $33.78 \%$ & 50 & $13.51 \%$ & 20 & $2.03 \%$ & 3 & $1.35 \%$ & 2 & 148 & 4.28 & $<0.05$ \\
\hline \multirow[t]{3}{*}{7} & $\begin{array}{l}\text { To identify the new, unknown, } \\
\text { rare of ADR }\end{array}$ & $58.50 \%$ & 86 & $30.61 \%$ & 45 & $8.84 \%$ & 13 & $1.36 \%$ & 2 & $0.68 \%$ & 1 & 147 & 4.45 & $<0.05$ \\
\hline & Answered & & & & & & & & & & & & 148 & \\
\hline & Skipped & & & & & & & & & & & & 3 & \\
\hline
\end{tabular}

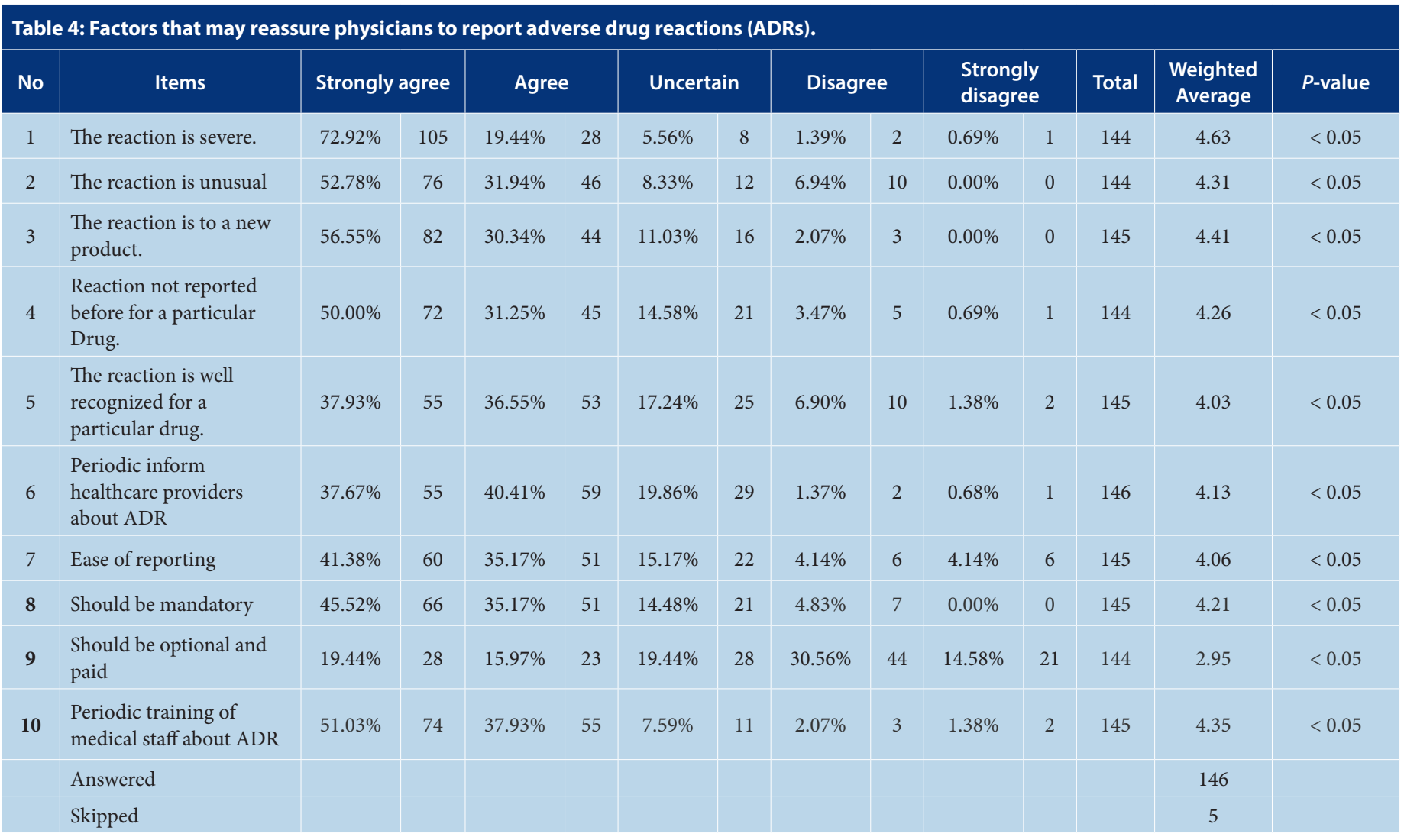

There is not any statistically significant relationship between factors (location, gender, age, qualifications, positions, years of experiences, physicians specialties and dentists specialties) and all physicians' impress about the prominence of ADRs reporting elements or factors that may assure physicians to report ADRs rudiments or factors that might avert physicians from reporting ADRs ( $p>0.05)$.

\section{DISCUSSION}

Over the past years, the healthcare system established very rapidly in the Kingdom of Saudi Arabia. ${ }^{[33,34]}$ The Saudi quality management system is well recognized among developing processes. ${ }^{[35]}$ Quality management services are obligatory from all 
Table 5: Factors that might prevent physicians from reporting adverse drug reactions. (ADRs).

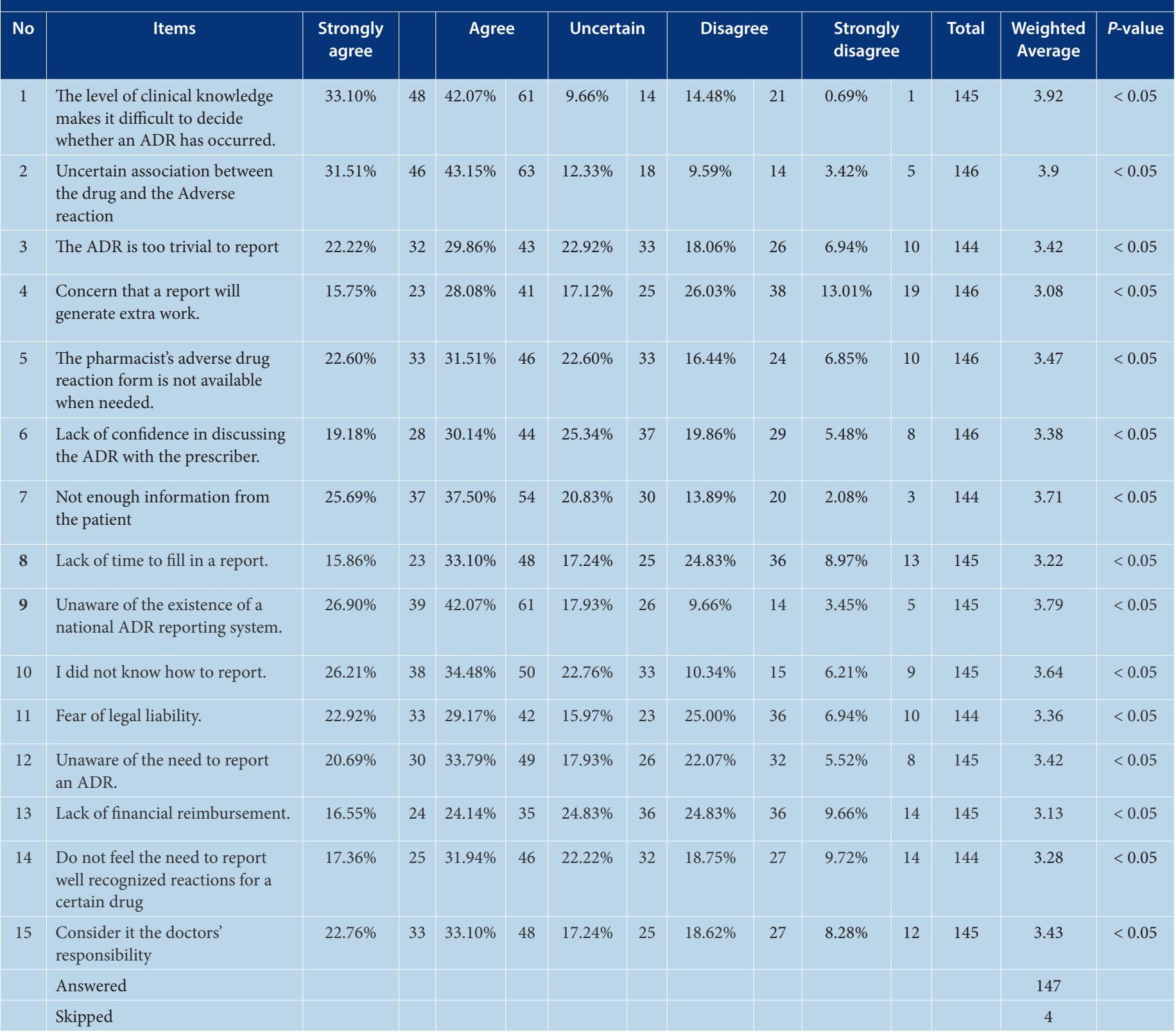

healthcare providers to report adverse effects it occurred. ${ }^{[35,36]}$ Besides, the Saudi Food and Drug Authority (SFDA) inspires all healthcare professionals to reports ADR. ${ }^{[37]}$ However, the ADR reports not sufficiently until now that's related might to the perception toward ADR lead to daily performances that were never reporting or under-reporting. As a result, the current study will discover physicians' perceptions and attitudes toward the ADR and three-part perception reporting system. The perception contained of a critical ADR reporting system, factors facilitate reporting methods and perception of barriers preventing ADR reporting system. In the study, the results of the first part of the high acuity of critical of ADR reporting system stating from the high score in predictions factors lead to ADR incidences or compare different manufacturing of medications, all rudiments essential were more eighty percepts of responders imitate the excellent of belief of critical of ADR and reporting system and look like the earlier studies. $^{[2,3,6,8,11-14,16-19,21,38-42]}$

The male gender had more contract than females in some important insights related to the made; maybe the male had more involved in the pharmacy committee than female, which uncovered reasons. The age level factor or level experience will not mark the ADR reporting system's importance. In contrast, with qualifications, the consultant more agreeable of some rudiments of the importance of ADR than residents might be related to the consultant physicians had more information and practice than residents of ADR reporting system, which entailed of the preceding study. [43] Besides, physicians who had more years' experience more agreement than others related more contact with pharmacy activity and hospital quality management services.

The results of the study of physicians insight of factors eased the ADR reporting was satisfactory with most rudiments factors with importance on critical elements that 


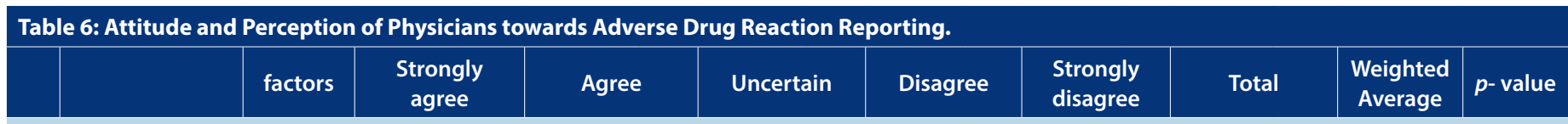

Gender factor affecting the perception of ADR reporting.

\begin{tabular}{|c|c|c|c|c|c|c|c|c|c|c|c|c|c|c|c|c|}
\hline 1 & $\begin{array}{l}\text { To enable safe } \\
\text { drugs to be } \\
\text { identified }\end{array}$ & Male & $80.25 \% *$ & 65 & $14.81 \%^{*}$ & 12 & $2.47 \%$ & 2 & $1.23 \%$ & 1 & $1.23 \%$ & 1 & $54.73 \%$ & 81 & 4.72 & $<0.05$ \\
\hline \multirow[t]{2}{*}{2} & \multirow{2}{*}{$\begin{array}{l}\text { To measure the } \\
\text { incidence of } \\
\text { ADRs }\end{array}$} & Male & $66.67 \%^{*}$ & 54 & $29.63 \%$ & 24 & $2.47 \%$ & 2 & $1.23 \%$ & 1 & $0.00 \%$ & 0 & $54.73 \%$ & 81 & 4.62 & $<0.05$ \\
\hline & & Female & $50.75 \% \%^{*}$ & 34 & $40.30 \%$ & 27 & $7.46 \%$ & 5 & $1.49 \%$ & 1 & $0.00 \%$ & 0 & $45.27 \%$ & 67 & 4.4 & $<0.05$ \\
\hline & $\begin{array}{l}\text { To compare } \\
\text { ADRs of the } \\
\text { same drug from } \\
\text { Different drug } \\
\text { companies. }\end{array}$ & Male & $56.79 \%^{*}$ & 46 & $28.40 \%$ & 23 & $11.11 \%$ & 9 & $2.47 \%$ & 2 & $1.23 \%$ & 1 & $54.73 \%$ & 81 & 4.37 & $<0.05$ \\
\hline
\end{tabular}

\section{Gender factor affecting the perception of facilitating of ADR reporting}

\begin{tabular}{|c|c|c|c|c|c|c|c|c|c|c|c|c|c|c|c|}
\hline \multirow{2}{*}{$\begin{array}{l}\text { The reaction is } \\
\text { to a new product }\end{array}$} & Male & $65.00 \%^{*}$ & 52 & $25.00 \%$ & 20 & $6.25 \%^{*}$ & 5 & $3.75 \%$ & 3 & $0.00 \%$ & 0 & $54.79 \%$ & 80 & 4.51 & $<0.05$ \\
\hline & Female & $46.15 \%^{*}$ & 30 & $36.92 \%$ & 24 & $16.92 \%^{*}$ & 11 & $0.00 \%$ & 0 & $0.00 \%$ & 0 & $44.52 \%$ & 65 & 4.29 & $<0.05$ \\
\hline $\begin{array}{l}\text { Reaction not } \\
\text { reported before } \\
\text { for a particular } \\
\text { Drug. }\end{array}$ & Male & $56.96 \%$ & 45 & $24.05 \%^{*}$ & 19 & $13.92 \%$ & 11 & $5.06 \%$ & 4 & $0.00 \%$ & 0 & $54.11 \%$ & 79 & 4.33 & $<0.05$ \\
\hline $\begin{array}{l}\text { Ease of } \\
\text { reporting }\end{array}$ & Male & $48.75 \%^{*}$ & 39 & $33.75 \%$ & 27 & $11.25 \%$ & 9 & $2.50 \%$ & 2 & $3.75 \%$ & 3 & $54.79 \%$ & 80 & 4.21 & $<0.05$ \\
\hline & Female & $18.46 \%$ & 12 & $24.62 \%^{*}$ & 16 & $15.38 \%$ & 10 & $30.77 \%$ & 20 & $10.77 \%$ & 7 & $44.52 \%$ & 65 & 3.09 & $<0.05$ \\
\hline
\end{tabular}

Gender factor affecting the perception of barrier preventing of ADR reporting

\begin{tabular}{|c|c|c|c|c|c|c|c|c|c|c|c|c|c|c|c|c|}
\hline & $\begin{array}{l}\text { Pharmacist's } \\
\text { adverse drug } \\
\text { reaction form } \\
\text { is not available } \\
\text { when needed. }\end{array}$ & Male & $25.93 \%$ & 21 & $23.46 \% *$ & 19 & $25.93 \%$ & 21 & $17.28 \%$ & 14 & $7.41 \%$ & 6 & $55.10 \%$ & 81 & 3.43 & $<0.05$ \\
\hline & \multirow{2}{*}{$\begin{array}{l}\text { Lack of } \\
\text { confidence in } \\
\text { discussing the } \\
\text { ADR with the } \\
\text { prescriber }\end{array}$} & Male & $17.50 \%$ & 14 & $22.50 \%^{*}$ & 18 & $28.75 \%$ & 23 & $25.00 \%$ & 20 & $6.25 \%$ & 5 & $54.42 \%$ & 80 & 3.2 & $<0.05$ \\
\hline 2 & & Female & $21.21 \%$ & 14 & $39.39 \% *$ & 26 & $21.21 \%$ & 14 & $13.64 \%$ & 9 & $4.55 \%$ & 3 & $44.90 \%$ & 66 & 3.59 & $<0.05$ \\
\hline \multirow{2}{*}{3} & \multirow{2}{*}{$\begin{array}{l}\text { Fear of legal } \\
\text { liability }\end{array}$} & Male & $26.58 \%$ & 21 & $20.25 \%$ * & 16 & $15.19 \%$ & 12 & $30.38 \%$ & 24 & $7.59 \%$ & 6 & $53.74 \%$ & 79 & 3.28 & $<0.05$ \\
\hline & & Female & $18.46 \%$ & 12 & $40.00 \%$ * & 26 & $16.92 \%$ & 11 & $18.46 \%$ & 12 & $6.15 \%$ & 4 & $44.22 \%$ & 65 & 3.46 & $<0.05$ \\
\hline \multirow[b]{2}{*}{4} & \multirow{2}{*}{$\begin{array}{l}\text { Unaware of the } \\
\text { need to report } \\
\text { an ADR. }\end{array}$} & Male & $20.00 \%$ & 16 & $26.25 \%^{*}$ & 21 & $17.50 \%$ & 14 & $27.50 \%$ & 22 & $8.75 \%$ & 7 & $54.42 \%$ & 80 & 3.21 & $<0.05$ \\
\hline & & Female & $21.54 \%$ & 14 & $43.08 \%^{*}$ & 28 & $18.46 \%$ & 12 & $15.38 \%$ & 10 & $1.54 \%$ & 1 & $44.22 \%$ & 65 & 3.68 & $<0.05$ \\
\hline
\end{tabular}

are comprised reporting of server ADR, or the medications were freshly added to the formulary or periodic training of medical staff with ADR reporting system, while lowest scores of well-known ADR or method using of reporting of ADR which contained with earlier studies. ${ }^{[2,12,13,18,22,38,43,44]}$ The ADR reporting system's hit critical points need to inform reporting system with directing with important points or transfer full accountability of ADR to the pharmacist can notice, document and follow-up all ADR reporting system linked issues.

The ADR system had barricades to employment. The physician's insight specified that's there is no satisfactory education and training of ADR reporting system during the school of medicines or medical practice while did not agree with high workload or repayment as encouraging factors that reproduce the physician's professionalism which contained with other studies. ${ }^{[13,14,19,38,40,43-46]}$ It reproduces to review medical schools their curriculum and add ADR reporting system and preliminary medications safety course encompassed ADR reporting system as part of the time. Several factors, comprising all age's stages, physicians' specialisms, physicians' qualifications, positions and years of experiences, will not vary in all rudiments of perception of ADR reporting system's reasons. Also, it does not make any alterations with factors facilitated or prevented ADR reporting system, which was contained with previous findings resemble ${ }^{[2,47])}$ and differ from other examination with positive 
perception with more experiences. ${ }^{[19]}$ There is no suggestion between all physicians answers in all three-part extrinsic of perception involved the importance of ADR reporting, encouraging factors of ADR reporting system and barriers preventing of ADR reporting system and location, gender, age, qualifications, positions, years of experiences, physicians specialties and dentists specialties that imitates those factors will not be connected and increases or decrease of elements scores of observations.

\section{Limitations}

The current survey showed various valuable information about physician's and dentist's insights of the ADR reporting system. However, the study had multiple confines, comprising physicians and a small number of dentists. The sample size of either physicians or dentists was not adequate to characterize the total number of physicians or dentists. Also, the number of qualifications or specialisms of both physicians and dentists were not equal. Most responders were young and low experiences, which varied from higher age and background. The future study of one type, either physicians or dentists with sample size and equal qualifications distribution is needed.

\section{CONCLUSION}

The current study was showed among physicians and dentists with an authenticated self-administered examination. The survey contained of several parts of perception of the ADR reporting system's aids, factors inspiring to report $\mathrm{ADR}$ and barriers discourage reporting of ADR with reviewed by expert reviewers \& showed pilot study and usage of various reliability test. The study's results presented a positive attitude and perception of critical ADR reporting systems that contained of many previous studies. ADR's noteworthy concern barriers were education and training about ADR and related issues, while the physicians distressed with extrawork or high load prevents a report of ADR. The physicians displayed a positive arrogance toward pharmacists to be responsible for the ADR reporting system. The updating ADR of changing policy and procedures of responsibility from all healthcare providers to pharmacists and directing education and training measured is an essential solution to improve the insight of ADR in the Kingdom of Saudi Arabia.

\section{ACKNOWLEDGEMENT}

None.

\section{CONFLICT OF INTEREST}

The authors declare that there is no conflict of interest.

\section{Funding}

None

\section{Consent for Publications}

Informed consent was obtained from all the participants

\section{Ethical Approval}

This research is exempted from research and ethical committee or an institutional review board (IRB) approval.

https://www.hhs.gov/ohrp/regulations-andpolicy/decision-charts-2018/index.html

\section{ABBREVIATIONS}

MOH: Ministry of Health; KSA: Kingdom of Saudi Arabia; ADR: Adverse Drug Reactions; SFDA: Saudi Food and Drug Authority; SPSS: Statistical Package of Social Science; JASP: Jeffery's Amazing Statistics.

\section{ORCID ID}

Yousef Ahmed Alomi iD https://orcid.
org/0000-0003-1381-628X

\section{REFERENCES}

1. Abubakar AR, Simbak NB, Haque M. A Systematic Review of Knowledge, Attitude and Practice on Adverse Drug Reactions and Pharmacovigilance among Doctors. J Appl Pharm Sci. 2014;4(10):11727.

2. Kamal NN, Kamel EG, Mahfouz EM. Adverse Drug Reactions Reporting, Knowledge, Attitude and Practice of Physicians towards it in El Minia University Hospitals. Int Public Heal Forum. 2014;1(4):13-7.

3. Abdel-Latif MMM, Abdel-Wahab BA. Knowledge and awareness of adverse drug reactions and pharmacovigilance practices among healthcare professionals in Al-Madinah Al-Munawwarah, Kingdom of Saudi Arabia. Saudi Pharm J. 2015 Apr 1;23(2):154-61

4. Al-Arifi MN, Mayet AY, Wajid S, Al-Saadi M, Babelghaith AEMISD, AIAyoubi FZ. Knowledge, attitude and perception of physicians towards adverse drug reaction reporting at king khalid university hospital, Riyadh, Saudi Arabia. Trop J Pharm Res. 2015;14(5):907-11.

5. Bakhsh T, Al-Ghamdi M, Bawazir S, Omer T, Qureshi N. Assessment of Hospital Physicians' Knowledge, Awareness, Attitude and Practice of Reporting Adverse Drug Reactions in Jeddah, Saudi Arabia. Br J Med Med Res. 2016;16(1):1-16.

6. Almandil NB. Healthcare professionals' awareness and knowledge of adverse drug reactions and pharmacovigilance. Saudi Med J. 2016;37(12):1350-5.

7. Ali MD, Hassan YA, Ahmad A, Alaqel O, Al-Harbi $\mathrm{H}$, Al-Suhaimi NM. Knowledge, Practice and Attitudes Toward Pharmacovigilance and Adverse Drug Reactions Reporting Process Among Health Care Providers in Dammam, Saudi Arabia. Curr Drug Saf. 2017;13(1):21-5.
8. Alsaleh FM, Lemay J, AIDhafeeri RR, AlAjmi S, Abahussain EA, Bayoud T. Adverse drug reaction reporting among physicians working in private and government hospitals in Kuwait. Saudi Pharm J. 2017;25(8):1184-93

9. Moinuddin K, Ali S, Al-Aqqad AQ, Salem SO, Al-Dossari MA, Ananzeh AM, et al. Knowledge and attitude of health-care professionals toward adverse drug reactions reporting at King Saud Medical City. J Pharm Bioallied Sci. 2018;10(1):2934

10. AlShammari TM, Almoslem MJ. Knowledge, attitudes \& practices of healthcare professionals in hospitals towards the reporting of adverse drug reactions in Saudi Arabia: A multi-centre cross sectional study. Saudi Pharm J. 2018;26(7):925-31.

11. Shroukh WA, Shakhatreh FM, Yasein NA, Sharkas GF. A survey on the knowledge, attitudes and practices of physicians towards pharmacovigilance in Jordanian health centres. Int Health. 2018;10(5):363-70

12. Upadhyaya HB, Vora MB, Nagar JG, Patel PB. Knowledge, attitude and practices toward pharmacovigilance and adverse drug reactions in postgraduate students of Tertiary Care Hospital in Gujarat. J Adv Pharm Technol Res. 2015;6(1):2934.

13. Nisa ZU, Zafar A, Sher F. Assessment of knowledge, attitude and practice of adverse drug reaction reporting among healthcare professionals in secondary and tertiary hospitals in the capital of Pakistan. Saudi Pharm J. 2018;26(4):453-61.

14. Lemay J, Alsaleh FM, Al-Buresli L, Al-Mutairi M, Abahussain EA, Bayoud T. Reporting of Adverse Drug Reactions in Primary Care Settings in Kuwait: A Comparative Study of Physicians and Pharmacists. Med Princ Pract. 2018;27(1):30-8.

15. Kassa AB, Biru TT. Health care professionals' knowledge, attitude and practice towards adverse drug reaction reporting and associated factors at selected public hospitals in northeast Ethiopia: A cross-sectional study. Biomed Res Int. 2019.

16. Nahar $\mathrm{N}$, Khan MTH, Banu LA, Khan MI, Hossain AM. Perceptions of Medical Practitioner Regarding Adverse Drug Reactions Reporting and Pharmacovigilance. J Shaheed Suhrawardy Med Coll. 2017;6(1):18-22. A

17. Haines HM, Meyer JC, Summers RS, Godman BB. Knowledge, attitudes and practices of health care professionals towards adverse drug reaction reporting in public sector primary health care facilities in a South African district. Eur J Clin Pharmacol. 2020;76(7):991-1001.

18. Binu KB, Sarika R, Denna SJ, Merin AA, Riya JHD et al. Assessment of Knowledge, Attitude and Perception Questionnaire Based Survey. Saudi J Med Pharm Sci. 2017;03(3A):124-32.

19. Adisa R, Omitogun TI. Awareness, knowledge, attitude and practice of adverse drug reaction reporting among health workers and patients in selected primary healthcare centres in Ibadan, southwestern Nigeria. BMC Health Serv Res. 2019;19(1):926

20. Güner MD, Ekmekci PE. Healthcare professionals' pharmacovigilance knowledge and adverse drug reaction reporting behavior and factors determining the reporting rates. J Drug Assess. 2019;8(1):13-20.

21. Nadew SS, Michael Beyene KG, Beza SW Adverse drug reaction reporting practice and associated factors among medical doctors in government hospitals in Addis Ababa, Ethiopia. PLoS One. 2020;15(1)

22. MM T, BC T. Assessment of Knowledge, Attitude and Practices of Adverse Drug Reaction Reporting among Doctors and Pharmacists in Primary Healthcare. Adv Pharmacoepidemiol Drug Saf. 2016;5(4):1-6

23. Gidey K, Seifu M, Hailu BY, Asgedom SW, Niriayo 
YL. Healthcare professionals knowledge, attitude and practice of adverse drug reactions reporting in Ethiopia: A cross-sectional study. BMJ Open. 2020;10(2).

24. Kamtane RA, Jayawardhani V. Knowledge, attitude and perception of physicians towards adverse drug reaction (ADR) reporting: A pharmacoepidemiological study. Int J Pharm Pharm Sci. 2012;4(Suppl. 4):698-704.

25. Paveliu MS, Bengea-Luculescu S, Toma M, Paveliu SF. Perception on adverse drug reaction reporting by physicians working in southern romania. Maedica. 2013;8(1):17-25.

26. Fatimah Fouad Al Doughan, Yousef Ahmed Alomi MHI. Pharmacist's Perception of Pharmacovigilance and Reporting of Adverse Drug Reactions in Saudi Arabia Fatimah. Int $\mathrm{J}$ Pharmacol Clin Sci. 2019;8(1):73-8.

27. Charan J, Biswas T. How to calculate sample size for different study designs in medical research?. Indian Journal of Psychological Medicine. 2013;35:121-6

28. Pourhoseingholi MA, Vahedi M, Rahimzadeh M. Sample size calculation in medical studies. Gastroenterol Hepatol from Bed to Bench. 2013;6(1):14-7.

29. Ezhumalai G. How big a sample do I need requir. Ann SBV. 2017;6(1):39-41.

30. Johnson TP, Wislar JS. Response rates and nonresponse errors in surveys.JAMA. 2012;307, 1805-6.

31. Erik von Elm, Douglas G. Altman, Matthias Egger, Stuart J. Pocock, Peter C. Gøtzsche JPV. The Strengthening the Reporting of Observational Studies in Epidemiology (STROBE) Statement: Guidelines for Reporting Observational Studies. PLoS Med. 2007;4(10):1623-7.

32. Von Elm E, Altman DG, Egger M, Pocock SJ, Gøtzsche PC, Vandenbroucke JP. The Strengthening the Reporting of Observational
Studies in Epidemiology (STROBE) statement: guidelines for reporting observational studies. Lancet 2007; 370: 1453-57.

33. $\mathrm{MOH}$ S. National E- Health Strategy - $\mathrm{MOH}$ Initiatives 2030. Ministry of Health Website. 2017. Available from: https://www.moh.gov.sa/en/ Ministry/nehs/Pages/vision2030.aspx

34. Saudi Ministry of Health. MOH stastistical report [Internet]. Ministry of Health, Saudi Arabia; 2017. 1-318 p. Available from: https://www.moh.gov. sa/Ministry/About/Documents/MOH_ANNUAL BOOKLET_2017 FINAL (1).pdf

35. Medication management system. Saudi Center Board for Accreditation for Healthcare Institutions (CBAHI). 2016

36. Alomi YA, Alghamdi SJ, Alattyh RA. National Adverse Drug Reaction Reporting System at the Ministry of Health, Saudi Arabia. Pharmacol Toxicol Biomed Reports. 2019;4(3):21-3.

37. Saudi Food and Drug Authority. Reporting adverse drug reactions [Internet]. [cited 2020 Nov 26]. Available from: https://www.google.com/search $? q=$ Saudi+Food +and +Drug+Authority.+Reportin $\mathrm{g}+$ adverse+drug+reactions\&rlz=1C1EJFC_enSA 930SA930\&oq =Saudi + Food + and + Drug + Authori ty.+Reporting+adverse+drug+reactions+\&aqs = chrome..69i57.1668j0j15\&sourceid=chrome\&ie = UTF-8

38. Oshikoya KA, Awobusuyi JO. Perceptions of doctors to adverse drug reaction reporting in a teaching hospital in Lagos, Nigeria. BMC Clin Pharmacol. 2009;9(4):1-8.

39. Ashraf Tadvi N, Alromaih AA, Aldahash AA, Almuhesseny AA, Alotaibi SH, Saad Alduhayshi I, et al. Knowledge, Attitude and Practice of Pharmacovigilance in Healthcare Professionals and Medical Students in Majmaah, Saudi Arabia Care Centre. Int J Med Res Heal Sci. 2018;7(4):101-7.

40. Saurabh MK, Karnani RK. An evaluation of knowledge, attitude and perception about adverse drug reactions and pharmacovigilance among intern doctors at a teaching hospital of Rajasthan Natl J Physiol Pharm Pharmacol. 2016;6(2):111-5.

41. Iffat W, Shakeel S, Rahim N, Anjum F, Nesar S, Ghayas S. Pakistani physicians knowledge and attitude towards reporting adverse drug reactions. African J Pharm Pharmacol. 2014;8(14):379-85.

42. Kunnoor NS, Singanal S, Lohit K. Perception of doctors towards Adverse Drug Reaction (ADR) reporting: A cross sectional survey using a validated questionnaire. Int J Basic Clin Pharmacol. 2017;6(11):2671.

43. Bakhsh T, Al-Ghamdi M, Bawazir S, Qureshi N Barriers, Facilitators, Strategies and Predictors for Reporting Adverse Drug Reactions in three General Hospitals in Jeddah, 2013. Br J Med Med Res. 2016:17(4):1-13.

44. Pimpalkhute SA, Jaiswal KM, Sontakke SD, Bajait CS, Gaikwad A. Evaluation of awareness about pharmacovigilance and adverse drug reaction monitoring in resident doctors of a tertiary care teaching hospital. Indian J Med Sci. 2012;66(34):55-61.

45. Hussain R, Hassali MA, Ur RehmanA, Muneswarao J. Hashmi F. Physicians' understanding and practices of pharmacovigilance: Qualitative experience from a lower middle-income country. Int J Environ Res Public Health. 2020;17(7):1-15.

46. Shamim S, Sharib SM, Malhi SM, Muntaha S ul, Raza H, Ata $S$, et al. Adverse drug reactions (ADRS) reporting: Awareness and reasons of under-reporting among health care professionals, a challenge for pharmacists. Springerplus. 2016;5(1):1778.

47. Bakhsh T, Al-Ghamdi M, Bawazir S, Al-Raddadi R, Qureshi N. Physicians Sociodemographics and Knowledge, Awareness, Attitude and Practice towards Reporting Adverse Drug Reactions: An Association Study in Jeddah City, Saudi Arabia. Br J Pharm Res. 2016;12(3):1-15. 